\title{
PEASANT REVOLUTIONISM OF THE COUNTRIES OF CENTRAL AND EASTERN EUROPE AND UKRAINE - THE CATALYST OF AGRARIANIST TRANSFORMATIONS
}

\section{Pasichna Yu. G.}

\section{INTRODUCTION}

Early twentieth century marked by significant socio-economic, sociopolitical, ethno-national transformations in Central and Eastern European countries. The challenges that arose and needed to be addressed urgently were due to the influence of the World War I and internal conflicts. One of the urgent issues was agrarian one. The search for ways to solve it and agrarian changes have radically influenced the course of world history. In the context of these changes, it is appropriate to single out a new phenomenon - agrarianism. Ukrainian agrarianism was one of the variants of Eastern European agrarianism.

The purpose of the study is to study the socio-economic and sociopolitical situation of the peasantry in Central and Eastern Europe and Ukraine and a comparative analysis of the revolutionary actions of the peasantry of Ukraine and Central and Eastern Europe, which accelerated the agrarianist transformations of society.

The topic we raised already has a historiographical tradition of coverage. The questions are consonant with our chosen topic for study, have become the subject of research by scientists. In particular, V. Boechko ${ }^{1}$, O. Sukhushyna ${ }^{2}$, S. Krapivin ${ }^{3}$, S. Kornovenko ${ }^{4}$ and others applied to their study. However, not all of them are fully covered.

1 Боєчко В. Вирішення аграрного питання в Польщі (1918-1926 pp.). Украӥнський селянин. 2018. вип. 20. С. 5-9.

${ }^{2}$ Сухушина О. Аграрні рухи в слов'янських країнах Центральної та ПівденноСхідної Європи та створення Зеленого Інтернаціоналу (1921-1924 рр.). Украӥнський селянин. 2008. Вип. 11. С. 337-341.

${ }^{3}$ Крапивин С. Транспортные пути эмали и их клиническое значение: дис. ... канд. мед. Наук : 14.01.21; Донецкий гос. медицинский ун-т им. М. Горького. Донецк, 1995. 126 с.

${ }^{4}$ Корновенко С., Земзюліна Н. Революційні потрясіння початку ХХ ст.: аграрне законодавство країн Центральної та Південно-східної Європи. Украӥнський селянин. 2018. Вип. 19. С. 45-49. 


\section{Socio-economic situation of the peasantry of Central and Eastern Europe and Ukraine in the early 20th century}

Agriculture formed the basis of the Bulgarian economy. The share of the rural population was $80.1 \%$. In 1908 , there were more than 225,000 owners in Bulgaria, who had 182,478 hectares at their disposal (the size of one land tenure was less than 2 hectares). At the same time, 215 owners owned 155,000 hectares (the size of each such household was over 300 hectares) ${ }^{5}$. The most numerous were households that can be called middle-peasants'. In 1908 the number of such households was 172 thousand, they had allotments ranging in size from 5 to 10 hectares ${ }^{6}$.

In the early twentieth century the peasantry of Bulgaria was in a difficult socio-economic situation: increased taxes, debts to the state and moneylenders, the problem of providing households by agricultural machinery, difficult rental conditions, and so on. The state placed the payment of foreign debts on the shoulders of the peasantry. The state tax doubled in 1911 compared with 1901. The peasant mortgage debt to banks and individuals in 1911 amounted to 38 million levs, compared with 11 million levs in 1901. The main agricultural tool of the landless peasantry and the poor was the ard. According to statistical estimates, in 1910 thousands of farms had an average of 849 ards, 231 plows, 2 seeders, 14 reapers, 2 threshers ${ }^{7}$. Most of all the peasantry in Bulgaria suffered from the conditions imposed by moneylenders. In many cases, the peasants were forced to give $1 / 2$ of the harvest to the usurers for debts ${ }^{8}$.

Rental conditions were also difficult. Peasants who had plots of about 3 hectares and leased no more than 5 hectares often applied for rent. The most difficult was the natural lease, the conditions of which were that often half of the harvest or even $2 / 3$ was taken by the landowner. In addition to in-kind rent, there was also a working one. It was approached by peasants who worked for export. Such households were provided with agricultural machinery and resorted to hiring labour' ${ }^{9}$. We have confirmation of the difficult economic situation of the peasantry in the reports of agricultural inspectors: "The situation of our landowner... is in most cases critical. Peasants work from dawn to dusk, not getting for their work and the most necessary"10.

\footnotetext{
${ }^{5}$ История Болгарии / ред. П.Н. Третьяков, С.А. Никитин, Л.Б. Валев. Москва : Издательство Академии наук СССР. 1954. Т. 1. С. 451.

${ }^{6}$ Ibid. C. 453.

${ }^{7}$ Ibid. C. 451.

${ }^{8}$ Ibid. C. 452.

${ }^{9}$ Ibid. C. 453.

${ }^{10}$ Ibid. C. 451-452.
} 
Under such difficult socio-economic conditions, peasant households went bankrupt, and peasants were forced to seek work. Not only households with less than 2 hectares of land were ruined, but also households ranging in size from 5 to 10 hectares. From the social structure of the peasantry, agricultural workers were separated, who, due to the difficult situation in industry, were forced to go to work for the wealthy peasantry. The total number of agricultural workers in 1910 was 190 thousand, of whom 90 thousand - permanent workers ${ }^{11}$. Working conditions were extremely difficult: the working day lasted 14-16 hours, wages were meager, women's work was paid half as much.

About $65 \%$ of the population was employed in Polish agriculture ${ }^{12}$. The social structure of the rural population of Poland at the beginning of the twentieth century. was divided into affluent peasantry - 14.5 million $(53.2 \%)^{13}$, middle peasants -5.5 million $(20.2 \%)$ and landless peasants 7.2 million (26.4\%). The basis was small households up to 5 hectares, which accounted for $2 / 3$ of all households. The wealthy peasantry (over 100 hectares) owned $44.8 \%$ of all lands, middle-peasants' households owned $27.3 \%$ of the land, and the landless peasantry owned $11.2 \%$ of the land ${ }^{14}$. 1.3 million peasants did not have land holdings, i.e., were landless. The Catholic church was large landowner in Poland and had 229 thousand hectares (each allotment was more than 50 hectares) ${ }^{15}$.

The agrarian problems of the Polish peasantry were caused by the influence of the World War I, the use of obsolete equipment, low labour productivity, the non-use of fertilizers, and the outdated system of land cultivation $^{16}$.

In Czechoslovakia's agriculture in the early twentieth century $39.57 \%$ of the population was employed ${ }^{17}$. Socially rural population of Czechoslovakia

${ }^{11}$ История Болгарии / ред. П.Н. Третьяков, С.А. Никитин, Л.Б. Валев. Москва : Издательство Академии наук СССР. 1954. Т. 1. С. 452.

12 Краткая история Полши. Москва : Наука, 1933. С. 263.

13 Зашкільняк Л., Крикун М. Історія Польщі. Від найдавніших часів до наших днів. Львів, 2002. С. 459.

14 Боєчко В. Вирішення аграрного питання в Польщі (1918-1926рр.). Украӥнський селянин. 2018. Вип. 20. С. 5.

${ }_{16}^{15}$ Краткая история Полши. Москва : Наука, 1933. С. 263.

16 Зашкільняк Л., Крикун М. Історія Польщі. Від найдавніших часів до наших днів. Львів, 2002. С. 460.

${ }^{17}$ Сухушина О. Аграрні рухи в слов'янських країнах Центральної та ПівденноСхідної Європи та створення Зеленого Інтернаціоналу (1921-1924 рр.). Украӥнський селянин. 2008. Вип. 11. С. 338. 
in the early twentieth century divided into small, medium and wealthy ${ }^{18}$. The agrarian problems facing the newly formed state were similar to those facing other Slavic countries: the effects of the World War I were compounded by insufficient food for both the rural and urban populations.

Czechoslovakia's agrarian problems did not become a new phenomenon for the newly formed state. Czech and Slovak lands at the turn of the nineteenth - twentieth centuries developed unevenly, including in the agricultural sector. By the end of the nineteenth century. Czech society managed to overcome the agrarian crisis and the rural population began to grow grain, potatoes, hops, and beets more actively ${ }^{19}$. However, the state was unable to control the uneven enrichment of the population and the number of hired rural workers, and hence the growth of smallholder and landless peasants. The total percentage of employees in cities and villages was $57 \%$ of the total population ${ }^{20}$.

In Slovakia at the turn of the nineteenth - twentieth centuries dominated by large land holdings, which territorially covered more than a third of all lands. Therefore, there were problems of land scarcity, ruin of peasant households and migration of the rural population to Hungary, Austria, USA and partly Russia, exploitation of the rural population in the form of various forms of work, various forms of lease of agricultural land that were unaffordable for the peasantry (for example, sharecropping arrangements, etc. $)^{21}$. The unification of the Czech and Slovak lands did not contribute to the development of agriculture. During the first third of the twentieth century there is an enrichment of large landowners and the impoverishment of small peasant households in Slovakia, which were unable to withstand market competition from large Czech industrial centres ${ }^{22}$.

At the beginning of the twentieth century $2 / 3$ of the rural population was employed in the agricultural sector of Dnieper Ukraine. For example, in 1917, out of 31,214.5 thousand inhabitants of the nine Dnieper Ukrainian provinces, 24,237.3 thousand were peasants $(77.7 \%)^{23}$. According to estimates by $\mathrm{Yu}$. Kotlyar, the peasants had 28 million dessiatins of land, or $64 \%$ of the total economic land area. In the regional division, each peasant household had: on the Right Bank - 5.4 des., on the Left Bank -6.8 des., in

18 Чехия и Словакия в XX веке: очерки истории: в 2 кн. / ред. В.В. Марьина. Москва : Наука, 2005. Кн. 1. С. 20.

${ }^{19}$ Ibid. C. 18.

${ }^{20}$ Ibid.

${ }^{21}$ Ibid. C. 34.

${ }^{22}$ Ibid. 453 c.

${ }^{23}$ Рибалка І. Великий жовтень і зміни соціальної структури селянства України (1917-1920 рр.). Украӥнський історичний журнал. 1987. № 11. С. 38. 
the South -8.5 des. ${ }^{24}$ At the same time, the size of landed estates averaged 1,740 des. on the household ${ }^{25}$.

The peasantry of Dnieper Ukraine was also in a difficult socio-economic situation: 1) objective processes of establishing market relations in agriculture, for which the peasants were not ready; 2) the preservation of the remnants of serfdom, and especially the workings, which were quite sensitive for the peasants. The most common were working for land leased by peasants from landlords; 3 ) performance in favour of the landlords and the state of numerous in-kind and monetary duties. Redemption payments remained the most significant among them. Due to chronic insolvency, peasants from year to year underpaid 10,20 percent or more of a certain amount of payment, which led to an increase in the amount of arrears; 4) poor harvest years, which were repeated in Russia with a frequency of 3-4 years ${ }^{26}$; 5) lack of labour in the countryside. About 4 million men of the countryside were mobilized for the army during the World War I; 6) by the spring of 1917 , a third of the peasants' horses had been requisitioned for the needs of the army ${ }^{27}$. The peasants were also burdened with food requisitions for the needs of the army, legalized on November 29, $1916^{28}$; 7) a sharp decrease in the supply of the village with agricultural equipment, machinery, such simple, but necessary for the peasants, tools such as sickles and scythes. At the beginning of 1917, every second peasant household did not have arable tools, in addition, it was forced to hire working cattle, because they also did not have their $\mathrm{own}^{29} .88 .46 \%$ of the poor and middle peasants did not have enough land, $88.1 \%$ - working cattle, $84.2 \%$ - cows, $44.9 \%$ - equipment ${ }^{30}$. If the landowner had 17 horses and 24 head of cattle, the poor -1.2 horses and 1.5 head of cattle ${ }^{31}$. S. Maslov, one of the leaders of the Socialist-Revolutionaries, considered the reason for the peasants' actions to be the peasantry's scarcity of land: "The need for

24 Котляр Ю. Селянство Півдня України в період економічної політики (1921-1929 рр.): дис... д-ра іст. наук: 07.00.01. Одеса, 2005.

25 Малькін В. Земельне питання в Україні в умовах революції 1917-1920 pp. : дис. ... канд. іст. наук: 07.00.01. Львів, 2009.

${ }^{26}$ Герасименко О. Селянський рух на Лівобережній Україні (1900 - лютий 1917 рр.) : дис. ... канд. іст. наук: 07.00.01. Чернігів, 2007. 285 с.

${ }_{27}$ Малькін В. Земельне питання в Україні в умовах революції 1917-1920 рр. : дис... канд. іст. наук: 07.00.01. Львів, 2009.

28 Мотенко Я. Селянський рух в Харківській губернії (1917-1921рp.): дис. ... канд. істор. наук : спец. 07.00.01. Харків, 2005. 195 с.

${ }^{29}$ Ibid.

${ }^{30}$ Куташев I. Селянський рух в Україні (березень 1917 р. - квітень 1918 р.): дис. ... канд. істор. наук : спец. 07.00.01. Київ, 2002. 236 с.

${ }^{31}$ Ibid. 
land is all over the country"32. According to K. Kononenko's calculations, the smallholder and landless peasantry of Ukraine made up a total of $78 \%{ }^{33}$.

Mobilization of the population, shortage of labour, tools, etc. have led to a sharp decline in productivity. For example, in Poltava region, in comparison with 1913, in 1917 the yield of rye in peasant farms decreased from 78 to 48 poods, winter wheat - from 97 to 37 poods, spring wheat - from 67 to 46 poods, barley - from 79 to 48 , oats - from 80 to 52 poods, etc ${ }^{34}$. However, despite the decrease in yields on the territory of Ukraine in peasant households, the export of fodder and food for the needs of the army only increased.

In addition, peasant farms had a low agricultural culture. Most of the land in peasant farms was cultivated by three-field and multi-field systems and so $\mathrm{on}^{35}$. Land yields in peasant households were half as low as in landlord and wealthy peasant households. Due to this, the peasants were forced to rent arable land. For example, in the Kharkiv province, the rental price in early 1917 was 20 rubles 20 kopecks per dessiatin ${ }^{36}$.

According to the research of Yu. Kotlyar, V. Malkin and I. Kutashev, the property differentiation of peasant households in 1917 was as follows:

Peasant households of Ukraine $(1917)^{37,38,39}$

\begin{tabular}{|c|c|c|c|}
\hline $\begin{array}{c}\text { Peasant } \\
\text { households }\end{array}$ & $\begin{array}{c}\text { according } \\
\text { to Yu. Kotlyar }\end{array}$ & $\begin{array}{c}\text { according } \\
\text { to V. Malkin }\end{array}$ & $\begin{array}{c}\text { according } \\
\text { to I. Kutashev }\end{array}$ \\
\hline $\begin{array}{c}\text { Without own } \\
\text { sowing }\end{array}$ & 700 thousand & 625 thousand & 633 thousand \\
\hline $\begin{array}{c}\text { With sowing up } \\
\text { to 1 tithe }\end{array}$ & - & 616 thousand & 625 thousand \\
\hline $\begin{array}{c}\text { With sowing } \\
\text { from 1 to 3 tithes }\end{array}$ & 800 thousand & 647 thousand & 657 thousand \\
\hline
\end{tabular}

${ }^{32}$ Маслов С. Земельный вопрос. Земля и воля. 1917. № 4. С. 1-2.

33 Кононенко К. Україна і Росія: Соціально-політичні підстави української національної ідеї 1917-1960. Мюнхен, 1965.

${ }^{34}$ Ревегук В. Полтавщина в добу Української революції 1917-1920 рр. Полтава, 2002. C. 93.

35 Мотенко Я. Селянський рух в Харківській губернії (1917-1921рр.): дис. ... канд. істор. наук : спец. 07.00.01. Харків, 2005. 195 с.

${ }^{36}$ Ibid.

${ }^{37}$ Котляр Ю. Селянство Півдня України в період економічної політики (19211929 рр.): дис. ... д-ра іст. наук: 07.00.01. Одеса, 2005.

${ }^{38}$ Малькін В. Земельне питання в Україні в умовах революції 1917-1920 pp. : дис... канд. іст. наук: 07.00.01. Львів, 2009.

39 Куташев І. Селянський рух в Україні (березень 1917 р. - квітень 1918 р.) : дис. ... канд. істор. наук : спец. 07.00.01. Київ, 2002. 236 с. 
Large landowners, who accounted for $0.8 \%$ of the population, owned $40 \%$ of the total land fund, while $57.6 \%$ of the low- and middle-income peasantry owned $11.5 \%$ of the land fund ${ }^{40}$.

At the beginning of 1917, during the World War I, we observed a contradictory social differentiation of peasant households. There were cases when wealthy peasants were redeemed from conscription to the army, while the poor were deprived of a single worker ${ }^{41}$. Therefore, the confrontation between different segments of the peasantry intensified. The situation was also aggravated by the fact that wealthy owners hired workers. In order to somehow improve their financial situation, the peasants combined work in agriculture with earnings in industry and renting land. The rent was too high for the peasant ${ }^{42}$. The peasantry of Ukraine leased 3.9 million dessiatins of landlord's land, for which he paid annually 60 million rubles ${ }^{43}$. This rental cost was half the value of the annual income. It is clear why not all households could afford to rent land. Therefore, poor and middle peasantry households were at risk of bankruptcy ${ }^{44}$. In addition, the number of farms increased, so there were not enough land plots to meet the needs of the entire rural population.

\section{Socio-political activity of the peasantry of Central-Eastern Europe and Ukraine in the early 20th century}

The difficult agrarian situation of the peasantry in Central-Eastern Europe, according to most researchers, was the impetus for the unification of the peasantry into various organizations and movements to defend their rights. For example, in Czechoslovakia it was the Republican Party of the Countryside or the Agrarian Party, in Poland it was the Polish People's Party (PSP) "Piast", and in Bulgaria it was the Bulgarian Agrarian National Union $(B A N U)^{45}$. The political programs of these parties were based on the ideas of

${ }^{40}$ Мотенко Я. Селянський рух в Харківській губернії (1917-1921рр.): дис. ... канд. істор. наук : спец. 07.00.01. Харків, 2005. 195 с.

${ }^{41}$ Мотенко Я., Шишкіна Є. Соціально-економічна характеристика селянства Харківської губернії напередодні Української революції 1917-1921 років. Вісник HTУ «ХПI». 2015. № 56 (1165). С. 48.

42 Лозовий В. Ставлення селянства України до влади в добу Центральної Ради (березень 1917 р. - квітень 1918 р.) : дис. ... д-ра іст. наук № 07.00.01, 2010. 466 с.

${ }^{43}$ Куташев I. Селянський рух в Україні (березень 1917 р. - квітень 1918 р.) : дис. ... канд. істор. наук : спец. 07.00.01. Київ, 2002. 236 с.

${ }^{44}$ Щербатюк В. Селянський повстанський рух на Київщині 1917-1923 pp. : сучасна історіографія проблеми. Украӥнський історичний журнал. 2010. № 3. С. 187.

${ }^{45}$ Сухушина О. Аграрні рухи в слов'янських країнах Центральної та ПівденноСхідної Свропи та створення Зеленого Інтернаціоналу (1921-1924 рр.). Украӥнський селянин. 2008. Вип. 11. С. 337-341. С. 338. 
agrarianism. The ideas of Ukrainian agrarianism were represented in the programs of the Ukrainian People's Community, the All-Ukrainian Union of Agrarians-Owners, and the Ukrainian People's Party ${ }^{46}$.

The main provisions of the concept of agrarianism are as follows: the establishment of peasant private ownership of land, the opposition of urban and rural areas, the secondary role of the industrial sector, the idealization of the economic function of cooperation and more. These principles formed the basis of the so-called "third" - the peasant path of social development ${ }^{47}$. The "peasant cooperative republic" was considered the ideal future ${ }^{48}$.

In our opinion, the focus of politicians on the development of possible ways to solve agrarian issues has become relevant due to the active sociopolitical activity of the peasantry.

G. Matveyev, referring to the analysis of Czech and Polish agrarianism, called one of the founders of this concept A. Zhabko-Popovych ${ }^{49}$, who, in our opinion, aptly characterized the peasantry as an active participant in socio-economic life of the state: “... Agriculture and landowners a separate independent economic and spiritual world, which has an extremely strong influence on the state of economic, social, political, cultural and moral life of the whole people. The idea of agrarianism is realized when the interests and reasonable requirements of both rural production and the population employed in it are taken into account, as well as when this population is provided in the social, cultural and political life of the people with a place that "rightfully" belongs to it"

O. Frankenberger - one of the ideologues of Czechoslovak agrarianism - was convinced that the peasantry alone is not able to solve all their agrarian issues. He argued that only the active participation of the state in solving these processes can move the solution of agricultural issues. According to the scientist, this can be done by influencing the peasantry on the authorities to defend the interests of the peasantry, for example, by the agrarian party ${ }^{51}$.

${ }^{46}$ Kornovenko S., Pasichna, Yu. Intellectual Bases of Ukrainian Agrarianism of the Revolutionary Epoch: Vyacheslav Lypynsky. Skhidnoievropeiskyi Istorychnyi Visnyk. 2021. Bun. 19. C. 107-121. doi: 10.24919/2519-058X.19.234292

47 Носкова А. К вопросу об аграризме и крестьянском движении в странах Центральной и Юго-Восточной Европы в межвоенный период. Советское славяноведие. 1981. № 2. С. 45.

${ }^{48}$ Ibid.

49 Матвеев Г. «Третий путь?»: Идеология аграризма в Чехословакии и Польше в межвоенный период. Москва : Издательство МГУ, 1992. С. 54.

${ }^{50}$ Ibid.

${ }^{51}$ Ibid. C. 61. 
Socio-political activity of the Polish peasantry intensified in the spring summer of $1919^{52}$. The actions of the peasantry were caused largely by the desire of the land of the peasantry to solve agrarian issues by carrying out agrarian reform. Peasant demonstrations were characterized by spontaneous seizure of land and agricultural equipment ${ }^{53}$. Therefore, during July 3 July 10,1919 , the government was forced to discuss agrarian changes in the state.

In the early 1930s, the pages of the Green Standard, the central Polish organ of the People's Party, stated: "The twelve years of the existence of independent Poland unequivocally say that no one will take care of the peasant and no one will raise him. Therefore, it is correct to say that the liberation of peasants from poverty and darkness should be a matter for the peasants themselves" ${ }^{\text {" }}$,

Before the unification of the Slovak and Czech lands, a wave of hunger riots swept across Slovakia, which the authorities were forced to use to suppress $^{55}$. The Czechoslovak government faced another challenge in the agricultural sector that it was unprepared for: the unification of agrarian Slovakia with economically developed Czech lands led to a surplus of cheap labour in the countryside, which hindered the introduction of new agricultural machinery and advanced farming methods. In this situation, small households suffered, and the rich - got rich $^{56}$. Peasant demonstrations engulfed Czechoslovakia as early as 1918. Peasants opposed the landlords. There were clashes between the peasantry and the police and army, which were involved in the suppression of peasant actions ${ }^{57}$.

Between 1918 and 1919, peasant uprisings took place in Bulgaria, catalysed by crop failures in the central and western regions of the country. During 1918 there was a migration of the Bulgarian population from these territories to the east. A new wave of peasant uprisings began in the spring of 1919. To understand not only the agrarian problems of the peasantry, but also the behaviour and motives of the Bulgarian peasantry in the struggle for their rights, we can give an example of the hunger riot in the village of Kilifarevo, Tarnovo region. The protest was suppressed by police, who used

${ }^{52}$ Краткая история Польши. Москва : Наука. 1993. С. 250.

53 Ibid.

${ }^{54}$ Матвеев Г. «Третий путь?»: Идеология аграризма в Чехословакии и Польше в межвоенный период. Москва : Издательство МГУ, 1992. С. 167.

55 Чехия и Словакия в ХХ веке: очерки истории: в 2 кн. / ред. В.В. Марьина. Москва : Наука, 2005. Кн. 1. С. 97.

${ }^{56}$ Ibid. C. 115.

57 Горанович, М. Крах зеленого интернационала: (1921-1938). Москва : Наука, 1967. $281 \mathrm{c}$. 
weapons, were injured and killed ${ }^{58}$. During 1919, the socio-political activity of the peasantry intensified, but the peasantry in its actions significantly focused on the Bulgarian Agrarian National Union.

In their demands, the peasantry of Bulgaria stated the need to solve agricultural issues. For example, on December 15, 1918, the villagers of the village of Palazar in the Osman-Pazar district, in an appeal to O. Stamboliysky, stated: "We ask you to submit a proposal to the parliament and annul all drafted acts and writs of execution by law. We have claimed many casualties during the three-year war in the regions, and now fines. There is a case when two brothers died in one family in the war, and now a tax collector comes and demands a fine of 400-500 levs" ${ }^{39}$. Then the peasantry declared: "Our food prices are low, and our shoes and coats are very high, and two months ago Minister Dragiev promised us lower prices" ${ }^{\text {00 }}$. In 1919 the political demands of the peasantry were added. In slogans to the authorities, the peasants declared: "Either act or go away" ${ }^{\circ 1}$.

In 1919, peasant demonstrations in Bulgaria became widespread and covered almost the entire territory of the state. The initiators of the peasant demonstrations in most cases were the peasants themselves, but in some situations the leadership of the Bulgarian Agricultural National Union called on the peasants to protest ${ }^{62}$. For example, in March 1919, on the initiative of O. Stamboliysky, mass gatherings of peasants were recorded ${ }^{63}$. In this way O. Stamboliysky tried to organize the peasantry. At one of these meetings on March 26, 1919, delegates from 38 "friendships" with a total number of 2.5 thousand members were present ${ }^{64}$. In this regard, P. Sorokin aptly noted that the socio-political activity of workers in continental Europe was replaced by peasant leaders and parties, which in some situations played a major role in the socio-political life of their countries ${ }^{65}$.

In Ukraine, the greatest socio-political activity of the peasantry gained in the autumn of 1917 in Kyiv, Volhynia and Podolia provinces. According to

${ }^{58}$ Крапивин С. Транспортные пути эмали и их клиническое значение: дис... канд. мед. наук: 14.01.21; Донецкий гос. медицинский ун-т им. М. Горького. Донецк, 1995. $126 \mathrm{c}$.

59 Человек на Балканах. Особенности «новой» южнославянской государственности: Болгария, Сербия, Черногория, Королевство СХС в 1878-1920 гг. Москва: Институт славяноведения РАН, 2016. С. 131.

${ }^{60}$ Ibid.

${ }^{61}$ Ibid. C. 133.

${ }^{62}$ Ibid. C. 139.

${ }^{63}$ Ibid. C. 140.

${ }^{64}$ Ibid.

${ }^{65}$ Ibid. 408 c. 
I. Kutashov's estimates, 849 peasant actions took place in SeptemberOctober $^{66}$. According to the research of Yu. Kotlyar, this figure is slightly lower: during July-October 1917 the number of agrarian actions reached $572^{67}$. During 1918-1919, the socio-political activity of the peasantry intensified. With the replacement of the Central Rada by Hetman Skoropadsky, and later with the coming to power of the Directory, peasant demonstrations did not stop. However, they became organized. In 1918 the peasants already had the experience of war. Yesterday's mobilized soldiers organized insurgent detachments around them, the ranks of which were replenished every day by people from the countryside ${ }^{68}$. In most cases, the rural poor joined such units ${ }^{69}$. If during 1917 the peasantry advocated only the solution of the agrarian issue, in 1918 the demands of the peasants acquired a political colour. The peasantry protested against the political regime $^{70,71}$.

By the end of 1920, the insurgent movement covered the entire territory of Ukraine. During 1918-1920, it was characterized by a variety of forms: from passive (criticism of the government, avoidance of mobilization) to active (pogroms, demonstrations, armed struggle) ${ }^{72}$, With the advent of Soviet power, the insurgent movement grew. The spontaneity of the insurgent units was replaced by their manoeuvrability and organization.

Peasant-insurgent actions of the 1920s were held under the slogans: "Down with the Bolsheviks", "For independent Ukraine" ${ }^{\text {"73 }}$. The actions of

\footnotetext{
${ }^{66}$ Куташов І. Селянський рух в Україні (березень 1917 р. - квітень 1918 р.) : дис. ... канд. іст. наук : 07.00.01. Київ, 2002. 236 с.

${ }^{67}$ Котляр Ю. Регіональні аспекти повстанського руху селян 20-х рр. ХХ ст. Проблеми історії Украӥни: факти, судження, пошуки. 2005. Вип. 13. С. 183-201.

${ }^{68}$ Попов I. Повстанський рух селян на Чернігівщині за доби Директорії (грудень 1918 - січень 1919 рр.). Сіверянський літопис. 2010. № 1-2. С. 150-157.

69 Верстюк В. Проблеми вивчення революційних аграрних перетворень на Україні. Украӥнський історичний журнал. 1983. № 10. С. 136-145.

70 Антонишин А. Селянсько-повстанський рух на Поділлі (квітень - листопад 1918 року. Історія. 2009. URL: http://politics.ellib.org.ua/pages-5233.html.

${ }^{71}$ Еткіна I. Селянські повстання в Чернігівській губернії у 1918 р.: причини та спрямованість. Сіверянський літопис. 2018. № 1-2. С. 363-368.

72 Резніков В. Селянський повстанський рух на Слобожанщині (1918-1923рp.): дис. ... докт. іст. наук : 07.00.01. Харків, 2016. 237 с.

73 Подкур Р. Збройний виступ як радикальна форма опору радянській владі в УСРР в 1920-ті - початку 1930 рр. (за матеріалами ВУЧК - ГПУ). URL: http://shron1.chtyvo.org.ua/Podkur_Roman/Zbroinyi_vystup_iak_radykalna_forma_oporu _radianskii_vladi_v_USRR.pdf.
} 
the peasantry during the first half of 1921 affected about 1.5 thousand people - supporters of Soviet power ${ }^{74}$.

Analysis of the socio-political activity of the peasantry in Central-Eastern Europe and Ukraine allows us to state that the peasantry played a decisive role in the early twentieth century. in the agricultural sector. In general, the sociopolitical activity of the peasantry in Central-Eastern Europe and Ukraine is characterized by radicalism and mass. Peasant demonstrations in Ukraine are marked by mass and radicalism. The peasantry of Czechoslovakia was the least active in protest activities, which is understandable, because the share of the rural population, compared to the countries we studied, was the smallest. The peasantry of Bulgaria and Ukraine showed political demands, the most active were large landowners in Poland.

Socio-political activity of the Polish peasantry became a catalyst for land reform. Land reform was regulated by the Seimas of 1919 and 1920 . According to the land reform, the forced sale of land by large landowners in excess of the established maximum at a price of $50 \%$ of its market value was introduced. However, large landowners proved a violation of their private law, which led to the suspension of land reform and the strengthening of socio-economic issues of the peasantry ${ }^{75}$. V. Boechko argues that the Land Law of the Legislative Sejm of July 10, 1919 was a "preliminary program of future legislative changes" 76 and did not solve not only the issues of landless peasants, but also agrarian issues in general.

The Czechoslovak government began agrarian changes on November 9, 1918. The law prohibited the sale of large plots of land. The law of April 16, 1919 established the maximum size of land allotment - 150 hectares of arable land and 250 hectares of total land allotment. The prices of non-land plots were set at the prices of 1913-1915. Most of the lands were received by middle owners ${ }^{77}$. Agrarian changes continued in Czechoslovakia until the 1930s. In total, landowners received $66 \%$ of arable land and $44 \%$ of other lands, so there is a well-established opinion about the partial implementation of agrarian changes in Czechoslovakia ${ }^{78}$.

74 Ганжа О. Українське село в період становлення тоталітаного режиму (1917-1927 рр.). Київ, 2000. 208 с.

75 Зашкільняк Л., Крикун М. Історія Польщі. Від найдавніших часів до наших днів. Львів, 2002.752 с. С. 460.

76 Боєчко В. Вирішення аграрного питання в Польщі (1918-1926 pp.). Украӥнський селянин. 2018. вип. 20. С. 7.

77 Чехия и Словакия в XX веке: очерки истории: в 2 кн. / ред. В.В. Марьина. Москва: Наука, 2005. Кн. 1. С. 109.

${ }^{78}$ Ibid. C. 110. 
It took a long time for the Bulgarian government to implement agrarian change. Despite peasant protests and demands for agrarian change, it was not until June 1919 that the Bulgarian Agrarian National Union decided at the XV Congress on the need for agrarian change in the state. The delay in agrarian reform was associated with the discussion and development of ways to implement it. On June 30, 1920, a bill was passed to increase the state land fund: land plots of more than 30 hectares were transferred to the state fund and were not cultivated by the owners ${ }^{79}$. In February 1921, a bill on labour land ownership was promulgated for discussion. The government sought to increase the land holdings of the landless peasantry by reducing the holdings of large landowners ${ }^{80}$. After discussion on April 25, 1921, the bill was passed. The bill set the maximum size of land ownership for those landowners who cultivated the land independently - 30 hectares. Landowners who did not work independently on land received: family - 10 hectares, single 4 hectares. Land plots that exceeded the established norm were transferred to the fund of "labour land ownership" municipal lands, and monastery lands were transferred to this fund. Such lands were supposed to be distributed among landless and landless peasants, displaced persons and emigrants, rural workers, and so on ${ }^{82}$.

To carry out agrarian reform in Bulgaria, public commissions of labour land ownership were established, the activities of which were regulated by district commissions and the Directorate of Labour Land Ownership. The composition of the commissions was regulated by a separate law. The commission could deprive the owner of the right to receive a plot of land. The land was provided for redemption at the prices of 1905-1915 with a surcharge of $20 \%$ in favour of the state. The owner received a document of ownership of land only after payment of the full value of the land allotment $^{83}$.

Agrarian reform provoked confrontation between large landowners and landless peasants. On September 2, 1921, certain changes were made to the law regarding the activities of the commission, but the changes strengthened the difficult socio-economic situation of the landless peasantry. The commission often committed corrupt practices in its work. This caused the intensification of the revolutionary activity of the Bulgarian peasantry. For example, the peasants of the village of Banitsa during a protest movement in

${ }^{79}$ История Болгарии / ред. П.Н. Третьяков, С.А. Никитин, Л.Б. Валев. Москва : Издательство Академии наук СССР. 1954. Т. 2. С. 67.

${ }^{80}$ Ibid. C. 68.

${ }^{81}$ Ibid.

82 Ibid.

${ }^{83}$ Ibid. 
1921 collected a resolution with 300 signatures against the work of the commission $^{84}$.

In December 1922, the land bill changed: the amount of redemption for land increased, which was economically beneficial to the wealthy peasantry; the maximum size of the land allotment, which was not subject to alienation, was increased, and so on ${ }^{85}$.

By June 9, 1923, the Bulgarian government had received 110,611 applications for land acquisition, of which 79,527 had received a positive response ${ }^{86}$. The number of landless and landless peasants was, as noted above, much larger, but the peasantry did not have the funds to buy land on such terms.

In Ukraine, the revolutionary nature of the peasantry also became an impetus for the authorities to find solutions to the agrarian issue. The starting point is the beginning of changes in the agrarian legislation of the Central Council is the First All-Ukrainian Peasants' Congress, which took place May 28 - June 2, 1917. In general, the legislative activity of the Central Council agrarian issues of the peasantry ${ }^{87}$. An important bill of the Central Council was the "Provisional Land Law" of January 18, 1918. The law abolished private ownership of land. Rural communities, township, county and provincial land committees were given property rights within the law. The labour norm was set - the amount of land that would meet consumer needs. The size of the labour norm and the term of its validity were determined by the land committees. The former owners and tenants had at their disposal those lands that they could cultivate without hired labour. The primary allotment of land concerned smallholder and landless peasants, and so on ${ }^{88}$.

After the legislative activity of the Central Council, P. Skoropadsky on April 29, 1918 in the charter "To all the people" restored private ownership of land, purchase and sale of land, to replace the land committees formed land and land liquidation commissions ${ }^{89}$. According to the new land bill of P. Skoropadsky's government, the formation of a land fund and the sale of

${ }^{84}$ История Болгарии / ред. П.Н. Третьяков, С.А. Никитин, Л.Б. Валев. Москва : Издательство Академии наук СССР. 1954. Т. 2. С. 68-69.

${ }^{85}$ Ibid. C. 69.

${ }^{86}$ Там же. С. 68.

${ }^{87}$ Берестовий А., Пасічна Ю. Аграрне законодавство Центральної Ради: вплив політичного чинника. Украӥнський селянин. 2018. Вип. 19. С. 8-14.

${ }^{88}$ Ibid. C. 11.

89 Аграрне законодавство періоду Української революції (1917-1921рр.): збірник документів і матеріалів / упоряд.: С.В. Корновенко, А. Г. Морозов, Ю. Г. Пасічна. Черкаси : Чабаненко Ю. А., 2019. С. 96. 
land to smallholder peasants and Cossacks was envisaged. Large plots of land were allowed to be sold only to the State Bank, and peasants were allowed to sell plots that did not exceed 25 dessiatins ${ }^{90}$.

The Government of the Directory of the Ukrainian People's Republic, which succeeded P. Skoropadsky's government, declared in a Declaration of December 26, 1918, that all small peasant farms remained in the use of the previous owners, while the rest of the lands were transferred to smallholder and landless peasants ${ }^{91}$. The Temporary Land Bill of the Directory of January 8, 1919 enshrined the abolition of private ownership of land, created land and state funds. Land plots of up to 15 tithes remained intact, and a labour norm of at least 5-6 tithes was established. Lands of national heritage passed into the disposal of labour unions and so on ${ }^{92}$.

\section{CONCLUSIONS}

Thus, the countries that were the subject of our study had many common features: they were all agrarian, most of the rural population were landless or landless peasants, and the government was slow to solve agrarian issues. The intensification of the difficult agrarian situation was due to the influence of the World War I, low tillage crops, insufficient provision of agricultural machinery, and so on. Therefore, the strengthening of socio-political activity of the peasantry as an active participant in socio-economic and sociopolitical processes is quite understandable.

In the countries of Central and South-Eastern Europe, the agrarian issue was quite clear. This is quite understandable, as the countries were dominated by the rural population, except for Czechoslovakia. The agrarian problems of the peasantry were exacerbated by the effects of the World War I, political transformations, and exacerbated by the growing exploitation of the peasantry. The countries of Central and Eastern Europe were shaken by a wave of peasant riots. Agrarian parties tried to control the revolutionary nature of the peasantry, but the socio-political activity of the peasantry in Central and Eastern Europe and, to a greater extent, Ukraine, had its own course of events. The peasantry declared itself an active participant in sociopolitical life. It is the revolutionary nature of the peasantry, in our opinion, was one of the reasons for the emergence of such a phenomenon as agrarianism.

90 Аграрне законодавство періоду Української революції (1917-1921рр.): збірник документів і матеріалів / упоряд.: С.В. Корновенко, А.Г. Морозов, Ю.Г. Пасічна. Черкаси : Чабаненко Ю.А., 2019. С. С. 134-138.

${ }^{91}$ Ibid. C. $188-194$.

${ }^{92}$ Ibid. C. 216-223. 


\section{REFERENCES}

1. Аграрне законодавство періоду Української революції (1917-1921 рр.): збірник документів і матеріалів / упоряд. : С.В. Корновенко, А.Г. Морозов, Ю.Г. Пасічна. Черкаси : Чабаненко Ю.А., 2019. 554 с.

2. Антонишин А. Селянсько-повстанський рух на Поділлі (квітень - листопад 1918 року. Історія. 2009. URL: http://politics.ellib.org.ua/pages-5233.html.

3. Берестовий А., Пасічна Ю. Аграрне законодавство Центральної Ради: вплив політичного чинника. Український селянин. 2018. Вип. 19. С. 8-14.

4. Боєчко В. Вирішення аграрного питання в Польщі (1918-1926 рр.). Український селянин. 2018. вип. 20. С. 5-9.

5. Верстюк В. Проблеми вивчення революційних аграрних перетворень на Україні. Украӥнський історичний журнал. 1983. № 10. C. $136-145$.

6. Ганжа О. Українське село в період становлення тоталітарного режиму (1917-1927 рр.). Київ, 2000. 208 с.

7. Герасименко О. Селянський рух на Лівобережній Україні (1900-лютий 1917 рр.) : дис. ... канд. іст. наук : 07.00.01. Чернігів, 2007. $285 \mathrm{c}$.

8. Горанович М. Крах зеленого интернационала: (1921-1938). Москва : Наука, 1967. 281 с.

9. Еткіна І. Селянські повстання в Чернігівській губернії у 1918 р. : причини та спрямованість. Сіверянський літопис. 2018. № 1-2. C. $363-368$.

10. Зашкільняк Л., Крикун М. Історія Польщі. Від найдавніших часів до наших днів. Львів, 2002. 752 с.

11.История Болгарии / ред. П.Н. Третьяков, С.А. Никитин, Л.Б. Валев. Москва : Издательство Академии наук СССР. 1954.

12. Кононенко К. Україна і Росія: Соціально-політичні підстави української національної ідеї 1917-1960. Мюнхен, 1965. 535 с.

13. Корновенко С., Земзюліна Н. Революційні потрясіння початку XX ст. : аграрне законодавство країн Центральної та Південно-східної Європи. Український селянин. 2018. Вип. 19. С. 45-49.

14. Котляр Ю. Селянство Півдня України в період економічної політики (1921-1929 рр.) : дис. ... д-ра іст. наук : 07.00.01. Одеса, 2005.

15. Крапивин С. Транспортные пути эмали и их клиническое значение : дис. ... канд. мед. наук : 14.01.21; Донецкий гос. медицинский ун-т им. М. Горького. Донецк, 1995. 126 с.

16. Краткая история Польши. Москва : Наука, 1933. 528 с.

17. Куташев I. Селянський рух в Україні (березень 1917 р. - квітень 1918 р.) : дис. ... канд. істор. наук : спец. 07.00.01. Київ, 2002. 236 с. 
18. Лозовий В. Ставлення селянства України до влади в добу Центральної Ради (березень 1917 р. - квітень 1918 р.) : дис. ... д-ра іст. наук № 07.00.01, 2010. $466 \mathrm{c}$.

19. Малькін В. Земельне питання в Україні в умовах революції 1917-1920 рр. : дис... канд. іст. Наук : 07.00.01. Львів, 2009.

20. Маслов С. Земельный вопрос. Земля и воля. 1917. № 4. С. 1-2.

21. Матвеев Г. «Третий путь?»: Идеология аграризма в Чехословакии и Польше в межвоенный период. Москва : Издательство МГУ, 1992. $239 \mathrm{c.}$

22. Мотенко Я. Селянський рух в Харківській губернії (1917-1921рр.) : дис. ... канд. істор. наук : спец. 07.00.01. Харків, 2005. 195 с.

23. Носкова А. К вопросу об аграризме и крестьянском движении в странах Центральной и Юго-Восточной Европы в межвоенный период. Советское славяноведие. 1981. № 2. С. 40-58.

24. Подкур Р. Збройний виступ як радикальна форма опору радянській владі в УСРР в 1920-ті - початку 1930 рр. (за матеріалами ВУЧК - ГПУ). URL: http://shron1.chtyvo.org.ua/Podkur_Roman/Zbroinyi_ vystup_iak_radykalna_forma_oporu_radianskii_vladi_v_USRR.pdf.

25. Попов I. Повстанський рух селян на Чернігівщині за доби Директорії (грудень 1918 - січень 1919 рр.). Сіверянський літопис. 2010. № 1-2. С. 150-157.

26. Ревегук В. Полтавщина в добу Української революції 1917-1920 рр. Полтава, 2002. 386 с.

27. Резніков В. Селянський повстанський рух на Слобожанщині (1918-1923 рр.) : дис. ... докт. іст. наук : 07.00.01. Харків, 2016. 237 с.

28. Рибалка І. Великий жовтень і зміни соціальної структури селянства України (1917-1920рр.). Украӥнський історичний журнал. 1987. № 11. С. 38-52.

29. Сухушина О. Аграрні рухи в слов'янських країнах Центральної та Південно-Східної Європи та створення Зеленого Інтернаціоналу (1921-1924 рр.). Український селянин. 2008. Вип. 11. С. 337-341.

30. Человек на Балканах. Особенности «новой» южнославянской государственности: Болгария, Сербия, Черногория, Королевство СХС в 1878-1920 гг. Москва : Институт славяноведения РАН, 2016. 408 с.

31. Чехия и Словакия в XX веке: очерки истории: в 2 кн. / ред. В.В. Марьина. Москва : Наука, 2005. Кн. 1. 465 с.

32. Щербатюк В. Селянський повстанський рух на Київщині 1917-1923 рр. : сучасна історіографія проблеми. Український історичний журнал. 2010. № 3. С. 186-204.

33. Kornovenko S., Pasichna, Yu. Intellectual Bases of Ukrainian Agrarianism of the Revolutionary Epoch: Vyacheslav Lypynsky. Skhidnoievropeiskyi Istorychnyi Visnyk. 2021. Bun. 19. C. 107-121. doi: 10.24919/2519-058X.19.234292. 